Milel ve Nihal, 13 (2), 2016

\title{
İslam Toplumlarında Şiddet Yanlısı Radikalleşme Nedenleri üzerine Bir İnceleme
}

Fatih YAMAN*

A Study on the Reasons for Pro-violence Radicalism in Islamic Societies

Citation/@): Yaman, Fatih, (2016). A Study on the Reasons for Pro-violence Radicalism in Islamic Societies, Milel ve Nihal, 13 (2), 32-61.

Abstract: Violence and terror impose themselves as undeniable realities in this century to the extent never experienced in human history. It is known that especially some radical structures and terrorist organizations instrumentalize various beliefs, particularly Islam, as a strategy of legitimizing and expanding their fields of action. However, the explanations provided for radicalization, which are based on a sterilized reason, and confined to certain well well-defined geographies are insufficient to understand it. Terrorism and radicalism are concurrently influenced by many factors, ranging from individual socio-psychological factors to many others such as political, ideological, economic, cultural etc. Because the situation is influenced by many factors, it needs to be examined comprehensively. Thus, such an examination necessitates an interdisciplinary approach, i.e. working on diverse social sciences such as on sociology, politics and international relations together. Today, the modern manifestations of pro-violence radicalization are experienced. With an understanding developed in the form of a political ideology, Islam is used in conjunction with various terrorist acts that have become a threat which have social, economic, and political effects on the global level. Considering this fact in this study, the analysis of the sociological basis of this reality will be discussed within the context of the approaches to violence and terrorism and the reasons for radicalism.

* Dr., İstanbul Üniversitesi, İlahiyat Fakültesi, Din Sosyolojisi Anabilim Dalı [fatih.yaman@istanbul.edu.tr] 
Key Words: Terror, Violence, Global Terror, Political Violence, Radicalism, Islamophobia.

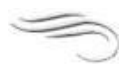

Atıf/C: Yaman, Fatih, (2016). İslam Toplumlarında Şiddet Yanlısı Radikalleşme Nedenleri Üzerine Bir İnceleme, Milel ve Nihal, 13 (2), 32-61.

Öz: Şiddet ve terörün içinde bulunduğumuz yüzyılda kendisini belki de insanlık tarihinde hiç olmadığı kadar yadsınamaz bir gerçeklik olarak dayatmakta olduğu görülmektedir. Özellikle kimi radikal yapı ve terör örgütlerinin, başta İslam olmak üzere çeşitli inançları kendi eylem alanlarını meşrulaştırma ve genişletme stratejisi olarak araçsallaştırdıkları bilinmektedir. Bununla birlikte radikalleşme olgusuna yönelik, sınırları belirlenmiş bazı coğrafi bölgeler üzerinden geliştirilecek ve tekil sebeplere indirgenebilecek açıklamalar yetersiz kalmaktadır. Zira terör ve radikalizm, bireysel sosyopsikolojik faktörlerden politik, ideolojik, ekonomik, kültürel vs. birçok faktöre uzanan unsurun eşzamanlı etkide bulunduğu bir durumu çok yönlü olarak incelemeyi gerektirmektedir. Kuşkusuz böylesi bir inceleme, konunun sosyoloji, siyaset bilimi ve uluslararası ilişkiler gibi çeşitli sosyal bilimler çerçevesinde disiplinler arası bir yaklaşımla ele alınmasını zorunlu kılmaktadır. Bu bağlamda şiddet yanlısı radikalleşmenin modern tezahürlerinin deneyimlendiği günümüzde, siyasal bir ideoloji şeklinde geliştirilen bir anlama biçimi olarak İslam'ın çeşitli terör eylemleriyle birlikte kullanılması ve bunun küresel düzlemde sosyal, ekonomik ve siyasal çıtıtıara mal olan bir tehdit halini almış olduğu gerçeğinden hareketle bu çalışmada, söz konusu realitenin üzerinde durduğu sosyolojik temelin çözümlenmesi, şiddet ve teröre yönelik geliştirilen yaklaşımlar ve radikalleşme nedenleri çerçevesinde ele alınacaktır.

Anahtar Kelimeler: Terör, Şiddet, Küresel terör, Siyasal şiddet, Radikalleşme, İslamofobi.

\section{Giriş}

Başta İslam, Hiristiyanlık ve Budizm gibi evrensel olarak kategorilendirilen dinler olmak üzere hemen hemen tüm dini geleneklerde temel insan hak ve değerlerinin korunumu merkezi bir önem taşımaktadır. ${ }^{1}$ Buradan hareketle insanın mutluluğunu hedeflediği çkarsanan dini geleneklerin zaman zaman doğrudan yahut dolaylı bir biçimde şiddetle özdeşleştirilmesi paradoksal bir durum olarak tartışlagelmektedir.

Özellikle içinde bulunduğumuz modern dönem dikkate alındığında, şiddet ve buna bağlı olarak gelişen terörün kendisini belki de insanlık tarihinde hiç olmadığı kadar yadsınamaz bir gerçeklik

${ }^{1}$ Şinasi Gündüz, Dinsel Şiddet, Samsun: Etüt Yayınları, (2002), s. 17. 
olarak dayatmakta olması din ve radikalleşme ilişkisini ele almayı zorunlu kılmaktadır. Zira sosyal, ekonomik ve siyasal alanda ortaya çıkan sonuçları bakımından terörün küresel bir tehdit olarak sunumlanmasından hareketle içinde bulunulan zamanın bir siber terörizm çağı olarak adlandırılmasına neden olduğu görülmektedir.

Radikalleşmeyi konu alan bir çalışmada yüzleşilen problemlerden ilki kuşkusuz konunun tek bir neden üzerinden değerlendirilemeyecek kadar çeşitlilik arz etmesidir. Buradan hareketle sosyal bir çıktı olarak terörü konu alan kapsamlı bir çalışmanın sosyo-kültürel, politik, ekonomik, dini ve entelektüel faktörleri de dikkate alması gerektiği ifade edilebilir. Konuyla ilgili ikinci problem ise olay yahut aktörler üzerinden yapılacak değerlendirmelerde öne çıkan "terör örgütü-terörist" gibi kavramların belirli bir aidiyet ve bakış açısına mensubiyetle ilgili yakın temasında aranmalıdır. Zira belirli bir halk yahut ülkenin "terörist" olarak nitelediği bir unsur farklı kesimlerce "özgürlük savaşçısı, gerilla, direnişçi" gibi tanımlamalarla ele alınabilmektedir.

Dolayısıyla terör ve terörizmle mücadele çerçevesinde ahlaki ve uygulanabilir bir sorumluluğun paydaşları olarak araştırmacıların konuyla ilgili kümülatif bir çabayı ortaya koyma gayretlerinin önemi öncelikli olarak teslim edilmelidir.

Özellikle 11 Eylül sonrası ABD'nin Afganistan ve Irak müdahaleleri ile dünya gündeminin önemli ilgilerinden biri haline gelen İslam, daha çok oryantalist bir bakış açısıyla şiddet, terör ve radikalleşmeyle birlikte anılmaya başlamıştır. Zira medyanın manipülatif etki potansiyelinin de dikkate değer bir biçimde sürece dahil olduğu bir çerçevede Müslümanlarla ilişkilendirilen şiddet eylemleri, hegemonyal amaçlar taşıyan dış müdahaleler, işgal ve baskı politikaları, küresel sömürü ve diktatöryel yönetimler göz ardı edilerek yalnızca İslam inancının doktriner metinleri bağlamında değerlendirilmeye açılmaktadır. Dolayısıyla kimi araştırmacılarca İslamofobi içerisine dahil edilebilecek türden nitelemelerle İslam, fanatizmin, tahammülsüzlüğün, şiddetin ve kanlı çatışmaların normallikle ele alındığı bir din olarak sunulmaktadır.2 Benzer şekilde İslam'ın çatışmacı bir

\footnotetext{
2 Bkz. John L. Esposito, The Islamic Threat: Myth or Reality?, Oxford: Oxford University Press, (1992); Antonio Cassese, Terrorism, Politics and Law: The Achille Lauro Affair, Cambridge: Polity Press, (1989).
} 
doğaya sahip olduğu önyargısından yola çıkılarak bir 'kılıç dini' olarak tanımlanmasi ${ }^{3}$, buradan hareketle de İslam medeniyetinin arkaik, ilkel, gerici ve çağın gerekliliklerine uyum sağlayamayan bir yapıyla özdeşliğini ortaya koyan yaklaşımlar karşımıza çıkmaktadır. ${ }^{4}$ Kuşkusuz bu türden değerlendirmelerde halihazırda nüfusunun büyük bölümü Müslümanlardan oluşan kimi ülkelerin demokratik olmayan otoriter rejimlerce yönetilmesi gibi hususlar da söz konusu yaklaşımları destekleyen bir argüman olarak kullanılabilmektedir.

Bu makale, İslam teolojisinde birincil kaynaklar olarak görülen metinlerin ne şekilde anlaşılması gerektiğine dair herhangi bir tartışma sunma iddiasında değildir. Bununla birlikte çalışma, siyasal bir ideoloji şeklinde geliştirilen bir anlama biçimi olarak İslam'ın şiddet ve terör eylemleriyle birlikte kullanılma gerçekliğinden hareketle, söz konusu realitenin üzerinde durduğu sosyolojik temelin çözümlemesini radikalleşme nedenleri bağlamında ele alacaktır.

Çalışmada, öncelikle konuyla ilgili tartışmalarda yer bulan kavramlar ilgili alan yazın çerçevesinde aralarındaki farklılıklara işaret edilerek ele alınacaktır. Ardından İslam toplumlarında gözlemlenen şiddet ve terör eylemlerini besleyen radikalleşme repertuarının hareket ettirici saikleri tartışlacak ve son bölümde ise söz konusu problematiğe yönelik geliştirilen çözüm önerilerine katkıda bulunulmaya gayret edilecektir. Kuşkusuz radikalleşmenin sebeplerini çözümleme ve tahlile yönelik böyle bir çalışmada konunun tüm yönleriyle eksiksiz bir biçimde ele alınması mümkün değildir. $\mathrm{Bu}$ sebeple çalışma, ilgili alan yazın içinde İslam toplumlarında özellikle son dönemde görülen şiddet içerikli radikal unsurların sosyolojik morfolojisini anlamaya yönelik mütevazi bir girişim olarak değerlendirilmeyi talep etmektedir.

\section{Tanımlama Problemi: Şiddet/Radikalleşme ve Terör Dolayımı}

İnsanoğlunun medenileşmesiyle orantılı olarak şiddetin azalacağ öngörüsünün yanlışlandığı günümüzde, şiddet olaylarının artması,

\footnotetext{
${ }^{3}$ Samuel P. Huntington, The Clash of Civilizations and the Remaking of World Order, London: Simon \& Schuster, (1996), s. 263.

${ }^{4}$ Bkz. Conor Cruise O'Brien, "Sick Man of the World", The Times, 11 May 1989, (akt.), Javaid Rehman and Susan C. Breau, Religion, Human Rights and International Law, London: Martinus Nijheff Publishers, (2007), s.5.
} 
şiddetle çeşitli biçimlerde yüz yüze gelinmesi ve gelişen kitle iletişim teknolojisiyle söz konusu durumlardan sıklıkla haberdar olunması, şiddete karşı duyarsızlaşmaların ve bunu normal kabul etme gibi durumların ortaya çıkmasına neden olmaktadır. Bu bağlamda modern insanın şiddeti, başta kendi hayatının özgül katmanlarında daha sonra da toplumsal yaşamın hemen her katmanında deneyimlediği söylenebilir. Başka bir deyişle adeta günümüzün yaşam tarzını karakterize eden şiddet, hem bireysel hem de toplumsal yaşamı biçimlemekte, organize etmekte; tercihlerimizi, hedeflerimizi yahut isteklerimizi etkileyerek hayatımızı kuşatmaktadır. ${ }^{5}$

Kavramların günlük konuşma dili ile alan yazın içinde kullanım kapsamlarının birbirinden önemli farklılıklar gösterebildiği gerçeğinden hareketle, gerek ilgili verinin toplanması gerekse bu verinin sınıflandırılarak ayrıntılı analizinin sağlanabilmesi için, kavramların açık ve anlaşılır bir şekilde ortaya konması önem arz etmektedir. ${ }^{6}$ Bu sebeple, öncelikle şiddet, radikalleşme ve terör gibi kavramların ilgili alan yazındaki karşılıklarının belirlenmesine ihtiyaç duyulmaktadır.

Şiddet kavramı sözlükte, "sindirmek, can acıtmak, öldürmek, cana yahut mala zarar vermek maksadıyla güç kullanmak, illegal olarak fiziksel güç kullanmak ve şiddet tehdidinde bulunmak" şeklinde tanımlanmaktadır.7 Başka bir ifadeyle şiddet, doğrudan siyasal bir amaç taşımayan ancak yok etmeye kadar varabilen tüm zarar oluşturucu saldırı eylemlerini kuşatan bir çerçeve sunmaktadır. ${ }^{8}$ Şiddetle ilgili tanımlamalarda görülen ortak nokta, fiziki güç kullanımın öne çıkmasıdır. ${ }^{9}$ Şiddet yalnızca insan vücuduna yahut mülke zarar verici bir saldırı olarak değerlendirilmemeli, bunun yanında

\footnotetext{
${ }^{5}$ Celal Türer, "Şiddetin Neliği ve Kavramsal Çerçevesi", Şiddet Karşısında İslam, (ed.), Bünyamin Erul, Ankara: Diyanet İşleri Başkanlığı Yayınları, (2015), s. 13.

${ }^{6}$ Giovanni Sartori, "Concept Misinformation to Comperative Politics", American Political Science Review, 64 (1970), s. 1033.

7 Türk Dil Kurumu, Türkçe Sözlük, Ankara:Türk Dil Kurumu Yayınları, (2005), s. 1866.; Tuncer Günay, Türkiye'de Terör ve Terörizm, Ankara: Berikan Yayınevi, (2001), s. 4.

${ }^{8}$ Doğu Ergil, Türkiye'de Terör ve Şiddet, Ankara: Turhan Kitabevi, (1980), s.3.

${ }^{9}$ Bkz. M. Şükrü Alparslan, Krimonoloji ve Hukuk Açısından Tedhişçilik, İstanbul: Teknik Yayınlar, (1983), s. 42-43.
} 
onun birey üzerinde psikolojik anlamda tahribatta bulunan bir yönünün de bulunduğu unutulmamalıdır. Nitekim şiddet, kimi dini örgütlenmeler eliyle bağlılarına yapılan birtakım telkinler yoluyla kişilerin baskı altına alınmasından söz konusu baskının ve uğranılan şiddetin etkisiyle intihar vakalarının görülebilmesine kadar varan geniş bir çerçeve sunmaktadır. ${ }^{10}$ Anlaşıldığı üzere şiddet, kişilerin zor yahut tehdit kullanılarak yaralanması, öldürülmesi gibi doğrudan bedensel zarar oluşturucu niteliğinin yanında, mallarının gasp edilmesi veya tahribi, gözdağı verilmesi ve baskı altına alınması gibi psikolojik boyutları da kapsayan geniş bir alanda tanımlanabilmektedir. Bununla birlikte bir siyasal toplulukta, doğrudan siyasal rejime, onun bileşenlerine, partilere veya uygulanan politikalara karşı gerçekleştirilen kolektif saldırılar ise "siyasal şiddet" olarak adlandırılan ${ }^{11}$ bir diğer şiddet formunu imlemektedir. Başka bir şekilde değerlendirilecek olursa, günlük ve sıradan şiddet türünde, yönelinen hedefe zarar verme amacına ulaşıldığında şiddet sona ermektedir. Dolayısıyla sıradan şiddet ile mağdur arasında ikili bir ilişkiden söz edilebilmektedir. Ancak siyasal şiddette fail, kurban ya da kurbanları tanımasa da onların ardındaki seyirci kitleye psikolojik mesajlar ileten bir araç olarak şiddeti kullanmaktadir. ${ }^{12}$

Bütün bu açıklamaların ötesinde şiddetin mahiyeti ve nedenselliğini açıklamaya girişen çeşitli disiplinlerin birbirinden farklı bakış açıları geliştirdikleri ifade edilmelidir. Sözgelimi konuya antropolojik bir yaklaşımla bakıldığında, canlıların kendi türlerinin devamlılığını sağlama eylemi olarak şiddeti kullanması söz konusu edilirken, psikolojik bir yaklaşımda şiddet, tedavi edilmesi gereken bir rahatsızlık yahut Freudyen bir bakışla, üstün gelme duygusundan veya ölüm gerçeğinden kaçma yolu olarak insanın başvurduğu yıkıcı bir eylem durumu şeklinde tarif edilebilir. Sosyolojik açıdan bakıldığında ise şiddetin toplumsal yapı ve işleyişe bağlı olarak öne çıkarıldığı görülecektir. Buna göre -Durkheimci bir yaklaşımla- bireyin şiddete olan yakınlığı içinde bulunduğu çevresel koşullarla

\footnotetext{
${ }^{10}$ Hayati Hazır, Siyasal Şiddet ve Terörizm, Ankara: Nobel Yayıncılık, (2001), s. 19.

11 John Richard Thackrah, Dictionary of Terrorism, London: Routledge, (2004), s.

202., Ted Gurr, Why Men Rebel, New York: Routledge, (2011), s. 4.

12 Günay, a.g.e., s. 50-51.
} 
örüntülenmiş toplumsal yapı tarafından belirlenebileceği gibi, şiddeti üretim ilişkilerinin bir sonucu olarak yorumlayan ve bu durumu oluşturan üretim tarzı aşıldığında şiddetin de aşılacağını savlayan bir yorumla da (Marksist yaklaşım) ele alınabilecektir. ${ }^{13}$

Öte taraftan 'radikal' kavramı ise "herhangi bir siyasal görüş konusunda taassub sahibi" 14 olmayı ifade etmekle birlikte, mevcut bir uygulama, kurumsal yapı yahut sosyal sistemin köklü bir şekilde değişimini talep eden kişi, grup ya da hareketleri nitelemek üzere kullanılmaktadır. Tarihsel süreçte siyasal olarak ilk kez Fransız devrimi sırasında krala karşı geliştirdikleri etkin muhalefetle öne çıkan kimseler için kullanılan bu tanımlama ${ }^{15}$, günümüzde, özellikle belirli dini inanç, ideoloji veya siyasi düşünceyi merkeze alarak geliştirilen "aşırılıkçı" tutumu betimlemektedir. Buradan hareketle radikalizm (radicalism), sosyal ve siyasal düzenin köklü yapısal dönüşümünün gerçekleşmesi adına siyasi araçların kullanımının ötesinde şiddete başvurmayı meşru gören grup davranışlarını nitelemek için kullanılan bir kavram olarak belirmektedir. Diğer bir deyişle, radikal eylemi demokratik herhangi bir talebi içeren bir eylemden ayıran başlıca unsur, şiddetin bir yöntem olarak benimsenmiş olmasıdır. ${ }^{16}$ Dolayısıyla radikalleşme, bireysel ya da kitlesel formda gelişen eyleme tarzında şiddetin kullanım meşruiyetini benimseyen bir yaklaşım olarak değerlendirilebilir. Bu yönüyle radikalleşme, mevcut sosyal yapı içerisinde düşünsel bir muhaliflikten başlamak üzere son tahlilde hedeflediği dönüşümü sağlamak amacıyla bir yöntem ve strateji olarak teröre başvurmayı olumlayan geniş bir çerçeve sunmaktadır. Kavramın son dönemlerde özellikle batılı araştırmacılarca ortaya konan çalışmalarda, fundamentalizm (fundamentalism) ile eş anlamlı olarak kimi dini toplumsal hareket-

\footnotetext{
${ }^{13}$ Celal Türer, "Şiddetin Neliği ve Kavramsal Çerçevesi", Şiddet Karşısında İslam, (ed.), Bünyamin Erul, Ankara: Diyanet İşleri Başkanlığı Yayınları, (2015), s. 21. 14 Ahmet Emin Dă̆, Uluslararası İlişkiler ve Diplomasi Sözlü̆̆̈̈̈, İstanbul: Anka Yayınevi, (2004), s. 371.

15 William Outhwaite and Tom Bottomore (ed.), The Blackwell Dictionary of Twentieth-Century Social Thought, Oxford: Blackwell, (1993), s. 541.

${ }^{16}$ Hilmi Demir, Radikal Selefi Hareketler ve Terör Örgütleri: Kavram ve Teorik Çerçeve, (Değerlendirme Notu), Türkiye Ekonomi Politikaları Araştırma Vakfı, (2016), s.45 .
} 
leri, özelde ise siyasal İslamcı yahut Cihatçı (Jihadist) olarak nitelenen aşırılık yanlısı ideolojik yapı ve örgütleri tanımlamak için kullanıldığı görülmektedir. ${ }^{17}$

Literatürde öne çıkan bir başka kavram çifti olan "radikal sağsağ radikalizm" ise, 1950'lerde Amerika'da yaygın olarak kullanılmaya başlanmış ve 1960'lardan itibaren diğer dillerde de yerleşmiştir. ${ }^{18} \mathrm{Bu}$ çerçevede $\mathrm{ABD}$ 'de radikal sağ kavramı, gelenekçi ve Hıristiyan fundamentalist değerleri benimseyen bir siyasi bakışla hareket eden akımları işaret etmek için kullanılmıştır. Bunun yanında Alman geleneğinde radikalizm, köklü siyasal değişim talepleri ileri süren ve çoğulcu temsili demokrasinin karşılıklı taviz ve pazarlık usulüne uzak duran hareketlerin niteliği olarak anlaşılmaktadır. ${ }^{19}$ Bugün ise çağdaş radikal sağ, sağ populizm, yeni populizm, radikal sağ populizm yahut neo-populizm gibi terimlerle karşılanabilmektedir. ${ }^{20}$

Şiddet ve radikalleşmeyle ilgili yukarıdaki açıklamalardan hareketle, "yıldırma, cana kıyma, korkutma ve tedhiş" gibi anlamlara gelen terörün ${ }^{21}$-her ne kadar üzerinde fikir birliği sağlanmış bir tanım henüz ortaya konmamışsa da' ${ }^{22}$ - genel olarak, savaş dışı durumlarda belirli hedeflere karşı siyasi amaçlara ulaşmak için şiddet veya tehdit kullanma biçiminde tanımlandığ 1 ifade edilebilir. ${ }^{23}$ Bu noktada terör ve terörizmin tarihsel olarak bir kaç bin yıl öncesine varan

${ }^{17}$ Bkz. John Esposito, The Islamic Threat, Oxford: Oxford University Press, (1999); Oliver Roy, The Failure of Political Islam, (Çev.), Carol Volk, London: I.B.Tauris, (1994); Lawrence Davidson, Islamic Fundamentalism, California: Praeger, (2013); Beverley Milton-Edwards, Islamic Fundamentalism since 1945, London: Routledge, (2005).

18 Klaus von Beyme, Right-Wing Extremism in Western Europe, London: Frank Cass, (1988), s. 2.

${ }^{19}$ Cas Mudde, "The War of Words Defining the Extreme Right Party Family", West European Politics, (1996), say1: 24, s. 232.

${ }^{20}$ Hasan Saim Vural, Avrupa'da Radikal Să̆ın Yükselişi, İstanbul: İletişim Yayınları, (2005), s. 25.

21 Türk Dil Kurumu, Türkçe Sözlük, Ankara: Türk Dil Kurumu Yayınları, (2005), s. 1961.

22 Gerek devletler ve uluslararası kuruluşlar gerekse araştırmacılar tarafından ortaya konmuş yaklaşık iki yüz civarında terör ve terörizm tanımının bulunduğu belirtilmektedir. Bkz. Fatih Yamaç, "Siber Terörizm”, Polis Dergisi, (2001), s. 29.

23 Rosalyn Higgins and Maurice Flory, Terrorism and International Law, London:

Routledge, (1997), s. xi. 
bir okuma biçimiyle ele alınmasının yanında, bu çalışmada konu edilen terör ve terörizm kavramlarının içinde bulunulan modern küresel çağın ürünleri olarak sorgulandığı hatırlanmalıdır. Zira modern dönemde terör, 19. Yüzyılda gelişen işçi hareketleri içerisinde teröre başvuranlarla şekillenen birinci dalga, 20. Yüzyılda bağımsızlık mücadeleleri ve soğuk savaş döneminde teröre başvuranların oluşturduğu ikinci dalga ve günümüzde devamlllı gösteren üçüncü dalga -küresel terör- olarak bölümlenmektedir. ${ }^{24}$ Fonksiyonel bir tanımlama yapılacak olursa, terör, baskı ve zorlama amacıyla, devlet dışı aktörler tarafından gerçekleştirilen siyasal güdülü ve planlı bir şekilde sürdürülen ve zaman zaman ulusal sınırları aşarak başka devletleri de hedef alan şiddet olaylarıdır. ${ }^{25}$ Benzer şekilde terörizm, saldırılan yahut korkutulan siviller aracıllğı ile hedeflenen daha büyük bir kitleyi yıldırarak yasa-dışı stratejik ve siyasal amaçların gerçekleştirilmesi için bir grubun bilinçli ve planlı bir biçimde şiddet kullanması veya kullanma tehdidinde bulunması şeklinde de tanımlanmaktadır. ${ }^{26}$ Her ne kadar bazı gruplar elinde terörün bizzat kendisinin amaçlaşması söz konusu edilebilirse de, terör, hedeflenen bir amaca ulaşma adına metot olarak kullanılan şiddetin yaygın bir formu olarak görülmektedir. ${ }^{27}$ Gürses ${ }^{28}$ ise çoğunlukla 'siyasi taviz koparmak amaciyla şiddet yoluyla toplumda korku salarak siyasi iktidara baskı yapma' durumunu terörizmin temel hareket ettirici unsuru olarak görmektedir. Bu noktada terör ve terörizm kavramları arasındaki farklılığa işaret etmek yerinde olacaktır. Terör, kısaca silahlı eylemler marifetiyle kendini ve davasını duyurma şeklinde özetlenebilirken, terörizm bu eylemleri savunan, stratejilerini açılayan, aktaran ve geliştiren bir düşünce disiplini yahut akımı ${ }^{29}$ şeklinde tanımlanmaktadır. Başka bir ifadeyle terör stratejik

\footnotetext{
24 İhsan Bal, “Terör Nedir? Neden Terörist Olunur?”, Terörizm, (Der.), İhsan Bal, Ankara: Usak Yayınları, (2006), s. 7.

${ }^{25}$ Talip Küçükcan, “Demokrasi, Din ve Küresel Şiddet Eylemleri”, İslam ve Şiddet, (Ed.), Mümtaz'er Türköne, İstanbul: Ufuk Kitap, (2007), s. 135.

${ }^{26}$ Doğu Ergil, "Terörizmin Mantığı ve Hedefi", Ankara Üniversitesi Siyasal Bilimler Fakültesi Dergisi, Ankara: Siyasal Bilgiler Fakültesi Yayınları, (1991), c. XLVI, sayı:1-2, s. 171.

27 Michel Wieviorka, "Terrorism in the Context of Academic Research", (içinde) Martin A. Miller, P. Pomper vd., Terrorism in Context, (ed.) M. Crenshaw, Pennsylvania: The Pennsylvania State University Press, (1995), s. 601.

${ }^{28}$ Emin Gürses, Etnik Terör, İstanbul: Profil Yayıncllık, (2007), s.13; Günay, a.g.e., s. 21.

29 İhsan Bal, a.g.e., s. 8.
} 
bir eylem olarak öne çıkarken terörizm uygulamaya konan stratejinin söylem çerçevesini imleyen bir yapıya sahiptir. Dolayısıyla terör eylemlerini nitelik açısından tanımlamayla ilgili ulusal yahut uluslararası bir anlaşmazlığın ortaya çıkması söz konusu olmazken, terörizmin içerdiği siyasal ağırlık ortak tanımlamayı zorlaştırmaktadır.

Siyasal içerikli bir kavram olan terörizmin, gerek içerik gerekse sınırlarının ikamesi açısından uluslararası platformda devletlerin tamamı tarafından kabul edilmiş, hangi türden eylemlerin terörizmi oluşturduğu ya da hangi aktörlerin terörist olarak değerlendirilmesi gerektiğine yönelik somut ve genelgeçer bir tanımı bulunmamakla birlikte, ${ }^{30}$ Avrupa Konseyi'nin 27 Aralık 2001 tarihli Terörle Mücadelede Özel Tedbirler Hakkındaki Ortak Tutum belgesinin 1. Maddesinde, terör eylemi son derece açık bir şekilde tanımlanmıştır. ${ }^{31}$ Buna göre terör eylemi, özelikleri ve bağlamı çerçevesinde bir ülkeye ya da uluslararası kuruluşa ciddi olarak zarar verebilecek, aşağıda ifadelendirilen amaçlarla işlenmesi halinde ulusal kanunlara göre bir suç olarak tanımlanmış olan kasıtlı filler anlamına gelir:

i. "Bir halkı ciddi olarak korkutmak,

ii. Bir hükümeti yahut uluslararası bir kuruluşu herhangi bir fiili gerçekleştirmeye ya da bu fiilden kaçınmaya zorlamak,

iii. Bir ülkenin ya da uluslararası bir kuruluşun temel siyasi, anayasal, ekonomik veya toplumsal kurumlarmı ciddi olarak istikrarsızlaştırmak ya da yıkmak:

a. Ölüme sebebiyet verebilecek şekilde bir kişinin hayatına kastedilen saldırılar,

b. Bir kişinin fiziksel sağlığına zarar verecek saldırılar,

c. Adam kaçırma yahut rehin alma,

d. Bir devlet ya da kamu tesisine, ulaşım sistemine, bilgi sistemleri, kıta sahanlı̆̆ üzerinde yer alan sabit platform türü tesisler dahil olmak üzere bir altyapı tesisine, bir kamu alanına ya da özel mülke

30 Javaid Rehman, Islamic State Practices, International Law and the Threat from Terrorism, Oxford: Hart Publishing, (2005), s.92.

${ }^{31}$ Kamu Düzeni ve Güvenliği Müsteşarlı̆̆ı İnsan Hakları ve Terörle Mücadele, Ankara: Kamu Düzeni ve Güvenliği Müsteşarlığı Yayınları, (2011), s. 17-19. 
insan hayatını tehlikeye atacak yahut önemli ekonomik kayıplara yol açacak şekilde zarar vermek,

e. Uçak, gemi ya da diğer toplu taşımacılık veya nakliye vasıtalarını kaçırmak,

f. Silah, patlayıcı madde ya da nükleer, biyolojik veya kimyasal silahların imalatı, bulundurulması, temini, taşınması, tedariki ile biyolojik ve kimyasal silahlarla ilgili araştırmalar yapılması ve bu tür silahların geliştirilmesi,

g. Tehlikeli maddelerin güvenliğini ya da insan hayatını tehlikeye atabilecek yangın, patlama veya su baskınlarına sebebiyet vermek,

h. İnsan hayatını tehlikeye atabilecek şekilde su, enerji ya da diğer temel kaynakların tedarikine müdahale etmek yahut tedariki kesintiye uğratmak,

i. Bir terörist grubu yönetmek,

j. Bilgi ya da maddi kaynak temin etmek, yahut herhangi bir şekilde faaliyetlerini finanse etmek yoluyla, bu tür bir katılımın grubun suç faaliyetlerine katkı sağlayacağını bilerek bir terörist grubun faaliyetlerine iştirak etmek.

$k$. ' $a$ ' ile ' $h$ ' bendi arasında yer alan fiillerden herhangi birini gerçekleştirmekle tehdit etmek."

Yukarıdaki verilerden hareketle 'terörist grup', ikiden fazla kişiyi ihtiva eden, zaman içinde teşekkül etmiş ve terör eylemi gerçekleştirmek üzere topluca hareket eden tarzda yapılanmış bir grup şeklinde anlaşılmaktadır. Bununla birlikte Birleşmiş Milletler Genel Kurulunca kabul edilen tanıma göre terör eylemi, "insan haklarını, temel özgürlükleri ve demokrasiyi yıkma amacı güden, devletlerin toprak bütünlüğünü ve güvenliğini tehdit eden, meşru olarak kurulmuş hükümetleri istikrarsızlığa uğratan, çoğulcu sivil toplumu tehlikeye atan, devletlerin ekonomik ve sosyal kalkınması üzerinde olumsuz sonuçlar doğuran faaliyetler" şeklinde ortaya konmaktadir. ${ }^{32}$

${ }^{32}$ Karar 54/164, Insan Hakları ve Terör, Genel Kurul tarafından 17 Aralık 1999 tarihinde kabul edilmiştir. (s.21). 
Kavramsal çerçeve içinde ayrıştırılması gereken kavram çiftinin sonuncusunu terörizm-anarşizm oluşturmaktadır. Zira kamuoyunda sıklıkla terörist ve anarşist ifadelerinin birbiriyle eş anlamlı kullanılması, diğer taraftan terörün toplumda anarşiye sebep olması ve anarşistlerin de kendi amaçlarına ulaşmada terör eylemlerine başvurmaları gibi hususlar söz konusu karışıklı̆̆ beslemektedir. Oysa anarşizm, devlet, hükümet, özel mülkiyet, din, aile gibi tüm örgütlü sosyal kurumları ortadan kaldırılması gereken bir sömürü aracı olarak konumlayan bir doktrinken; terörizm, devlet, hükümet ve diğer örgütlü kurumları yok etmeyi değil, amaçları doğrultusunda değiştirmeyi, yeniden yapılandırmayı amaçlayan bir tutum sergilemektedir. Başka bir deyişle, anarşist düşüncede hedeflenen, örgütsüz anarşik topluma ulaşmak iken, terörist bir yapı için varılacak nihai nokta, kendi siyasal ideolojisine uygun özellikler taşıyan yeni bir toplum ve yönetim anlayışını ikame etmektir. ${ }^{33}$ Kuşkusuz ikisi arasındaki ortak nokta, hedeflenen amaca ulaşmak için bir strateji ve teknik olarak teröre başvurmalarıdır.

\section{Radikalleşmeyi Doğuran Repertuar}

Sosyal bilimlerin siyasal terör, terörizm ve şiddet gibi temalarını çalışmalarına konu edinen araştırmacılar genel olarak radikalleşmenin, özel olarak da dini fanatizmin kimilerince terörün başlıca gerekçesi olarak değerlendirildiğine şahit olmaktadır. Esasen söz konusu fanatizmin terörizm için uygun zeminin oluşumuna katkı sağladığı, ancak bunun temel hareket ettirici etkeni olmadığı ifade edilmelidir. Başka bir deyişle, psikolojik, fizyolojik yahut otoriteryan biçimlerde uygulanabilen her şiddet hareketinin kendi meşruiyetini ikame etme aracı olarak bazen dinsel bir inanışa, bazense siyasal yahut ideolojik bir metin/söylem veya argümana dayandırma gerekliliği duyduğu bilinmektedir. ${ }^{34}$ Fakat diğer yandan pratik düzlem söz konusu edildiğinde dini düşünce ve hissiyatını görece 'radikal' olarak konumlayan bir çok insanın herhangi bir şiddet biçimini tercih etmeme örnekliği sunduğu da görülmektedir. Dolayısıyla, eylem biçimini en uç noktada teröre vardıran radikalleşmenin varlık kazanmasında şiddeti, mevcut toplum siyasasında

33 Türkiye Barolar Birliği, Türkiye ve Terörizm, Ankara: Şen Matbaa, (2006), s. 137138.

34 Şinasi Gündüz, a.g.e., s. 26. 
bir biçimde değişim oluşturmanın etkili bir yolu olarak görme durumuna sebep olan farklı etmenlerin bulunması gerekliliğine kapı aralanmaktadir.

Öte yandan, terörü doğuran başlica etmen olarak yoksulluğun yahut etnik farklılığın işaret edilmesi de alanla ilgili sosyolojik çözümleme ve gerekçelendirmelerde kolaycılığa kaçıldığının bir göstergesi olarak okunabilir. Zira özellikle Afrika, Asya ve Güney Amerika'nın bazı bölgelerinin yoksulluk düzeyleri ve bu bölgelerdeki toplumların terör ve şiddetle aralarına koydukları mesafe, öte taraftan aynı etnik kökene sahip unsurlar arasında da son derece büyük sayılara varan kayıpların yaşandığı terör faaliyetlerinin gerçekleşebildiği dikkate alındığında söz konusu ilişkinin daha farklı bir biçimde ele alınması gerekliliği ortaya çıkmaktadır.

Benzer şekilde demokratik olmayan yönetim anlayışlarının da terörün bizatihi sebebi olduğu iddiasının Çin yahut Kuzey Kore gibi demokratik olmayan ancak herhangi bir terör pratiği içinde yer almayan örneklerle yanlışlandığını gözlemlemek mümkündür. Tersinden bir okumayla, demokrasinin yerleşik olarak işletildiği kimi toplumsal yapılarda bizzat demokratik anlayış çerçevesinde geliştirilen özel hayatın dokunulmazlığı, seyahat özgürlüğü ve serbest ekonomik girişim gibi hususların terör örgütlenmelerinin mobilizasyonunda önemli kolaylıklar sağladığına yönelik değerlendirmeler yapılabilmektedir. ${ }^{35}$ Buradan, demokrasinin şiddet yanlısı bir radikalleşmeye doğrudan bir etkide bulunduğu anlamı çıarılamasa da özgürlükler bağlamında taşıdığı güvenlik zafiyetinden hareketle radikalleşmenin ve terörün varlık kazanmasına uygun bir zemin oluşturabildiği ifade edilebilir.

Bir başka indirgemeci yaklaşım örneğini, radikalleşme ve şiddetin temel kaynağının eğitimsiz insan profiliyle açılanabileceğine dönük anlatı oluşturmaktadır. Fakat ortaya konan şiddet eylemlerinin mahiyeti, kapsam genişliği ve etkileri göz önüne alındığında planlı ve stratejik önem düzeyleri titizlikle gözetilen eylemlerin profesyonel bir eğitim gerektirdiği anlaşılmaktadır. Bu da -en azındaneylem organizatörlerinin entelektüel olarak görece yüksek bir eğitime sahip olduklarını, dolayısıyla çatışmanın hazırlayıcısı olan -son

${ }^{35}$ Talip Küçükcan, “Demokrasi, Din ve Küresel Şiddet Eylemleri”, İslam ve Şiddet, (Ed.), Mümtaz'er Türköne, İstanbul: Ufuk Kitap, (2007), s. 138-139. 
zamanlarda öne çıkan bir kavram ile ifade edilecek olursa- üst aklın yüksek eğitsel donanıma sahip kimselerden örülü bir anlayışla işlediğini ve bu doğrultuda siyasal ve sosyal yapıda somut birtakım değişimler hedeflediğini göstermektedir.

Görüldüğü üzere insan tekinin eyleme ve etkime potansiyelini fazlasıyla aşan bir olgusal gerçeklik olarak şiddet ve terörle özdeşleşebilen radikalleşme sürecini tekil bir nedensellik üzerinden değerlendirmek eksik ve hatalı çıkarımlarda bulunmayı kaçınılmaz kılmaktadır. Zira radikalleşme, esasen dayandığı arka plan açısından çok yönlü bir yapıya sahiptir; dolayısıyla konunun yalnızca bir sebep üzerinden indirgemeci bir yaklaşımla değil, toplumsal, ekonomik, siyasal ve kültürel unsurların sürece eş zamanlı dahil edildiği bir biçimde ele alınması gerekmektedir. Buradan hareketle örneğin yalnızca dinle ilintili olarak değerlendirilebilecek türde bir radikalleşme/şiddet/terör olgusunun dahi arkasında kimi politik, ekonomik ve sosyal nedenler içermekte ${ }^{36}$ olduğu ifade edilebilir.

Bununla birlikte radikalleşmenin gerekçeleri ve mahiyetine yönelik her ne kadar genel geçer kimi kategorilendirmelerin yapılması mümkünse de ülke ve toplumlara göre birtakım özel nedenlerin de var olabileceği ve bunların da en az diğer sebepler kadar önem taşyabileceği göz önünde bulundurulmalıdır. Zira tıpkı bir ülkenin deneyimlediği terörizm özeline indirgendiğinde karşılaşılan algılama ve tanımlamalarda olduğu gibi radikalleşmeye dönük nedenleri içeren repertuar da objektiflik ve bilimsellik açısından benzer eleştirilebilir açıklığa sahip bir çerçeve sunmaktadır. Fakat yine de açıklama yönüyle en akılcı girişim olarak görülebilecek bu değerlendirme biçimi söz konusu edildiğinde, radikalleşmeye dönük repertuarın "sosyal nedenler ve toplumsal yapı, ekonomik nedenler, siyasal nedenler ve konjonktürel gelişmeler, hukuki yapı ve adalet anlayışı, jeopolitik ve jeostratejik nedenler, milletlerin ırki, kültürel, dini ve ideolojik yapısal özellikleriyle ilgili nedenler, emperyalist dış politikalar ve kişisel psikolojik sapmalar" ${ }^{\prime \prime 7}$ türünden başlıklar altında toplanabileceği ifade edilebilir.

Başka bir açıdan bakıldığında şiddet, terör ve buna ilişkin olarak görülen radikalleşme fenomeninin, objektif olarak tartışılması gereken davranışsal, sosyal ve entelektüel bağlamlara sahip olduğu

\footnotetext{
${ }^{36}$ Gündüz, a.g.e., s. 25.

37 Türkiye Barolar Birliği, a.g.e., s. 175-176.
} 
ifade edilebilir. Çünkü söz konusu eylem formlarına yönelen kimse ve grupların içinde bulundukları toplumca onaylanması, kendilerine bu yönde maddi destek bulmaları ve süreç içinde entelektüel gelişim sağlamaları ile mümkün olabilmektedir. Dolayısıyla aşağıda detaylı olarak yer verilen hususlar, radikalleşme bağlamında birbirlerine etkiyen ve eş zamanlı olarak değerlendirmeye alınması gereken bir tarzda irdelenmelidir.

\section{(i) Radikalleşmenin Sosyo-Psikolojik Düzlemi}

Radikalleşme ve terörizmin kesiştiği bir eksen üzerinde yapılan kimi değerlendirmelerde terörizmin ancak belli ülkelerde (gelişmemiş yahut gelişmekte olan) ve toplumlarda, belli koşulların varl1ğıyla ortaya çıkabileceğini, buna bağlı olarak teröristlerin önemli bir bölümünün de çeşitli psikolojik rahatsızlıklar ve hatta kalıtımsal kişilik bozuklukları ile malul olabileceklerini savlayan düşüncelere rastlanmaktadır. ${ }^{38}$ Ancak bu türden yaklaşımların zayıf ve eleştiriye açık yanı, gelişmiş ülkelerde ortaya çıkan terörist yapılanmaları (Örneğin Kızıl Tugaylar ya da Japon Kızıl Ordusu gb.) ve örgüt mensuplarının psikolojisini açıklamakta yetersiz kalışıdır. Zira terör eyleminde aktif rol alan kimselerin psikolojik olarak kimi sorunlarla özdeşleştirilmeleri mümkün kılınabilirse de, bu durum kalıtımsal yollarla gerçekleşen şiddet meyilli bir karakter aktarımından çok sosyo-psikolojik düzeyde yaşanan bir yabancılaşma, engellenme ve bunun sonucunda gerçekleşmesi mümkün görülebilecek bir isyan ve başkaldırı reaksiyonu olarak değerlendirilmektedir. ${ }^{39}$ Bilindiği üzere küçük yaşlarda aile tarafından konulan yasaklar olarak alg1lanan engelleme, ileriki yaşlarda birey tarafından bürokrasi ve devlet eliyle ikame edilen sinırlamalarla pekiştirilmekte, bu da birey üzerinde tepkisel bir durumun gelişmesine neden olmaktadır. ${ }^{40}$ İlerleyen süreçte kendi olanaklarılya eriştiği bilgileri öncesinde kendisine benimsetilen düşünce kalıplarını, değer yargılarını ve kontrol mekanizmalarını sorgulamak için kullanan birey, giderek dahil olduğu toplumsal kurumlardan uzaklaşma ve yabancılaşma yaşayabilmekte, sonrasında ise hayatın yönlendiriciliğini tanzim edecek güce sahip olduğunu düşündüğü karizmatik bir lider yahut otorite

\footnotetext{
38 Bkz. Walter Laqueur, Terrorism, Boston: Little, Brown, (1977), s. 125; Maxwell Taylor, The Terrorist. London: Brassey's, (1988).

${ }^{39}$ Haluk Yavuzer, Çocuk ve Suç, İstanbul: Remzi Kitabevi, (2006), s. 138.

${ }^{40}$ Haluk Yavuzer, Çocuk Psikolojisi, İstanbul: Remzi Kitabevi, (2005), s. 136-137.
} 
arama ihtiyacı duyabilmektedir. Kendi toplumuna yabancılaşan birey, son noktada, gereksinim duyduğu başkaldırıyı topluma ve nihayet devlet mekanizmasına yöneltebilecek bir hazır bulunuşluğa evrilebilmektedir. Anlaşıldığ sağlayan temel etmen, sürekliliği sağlanacak olan bir ötekinin var k1lınmasıdır. Dolayısıyla dünya bu perspektiften "biz" ve "onlar" arasında bitmeyen bir mücadelenin sürdüğü bir çatışma alanı olarak konumlanmaktadir. ${ }^{41}$

Öte taraftan radikalleşme ve teröre yönelimle ilgili kısıtlı da olsa yapılan saha araştırmalarından derlenen bilgilere göre ${ }^{42}$ teröristlerin haklarını elde etmek adına başvurulacak başka bir yöntemin kalmadığına yönelik bir inanca vardıkları, dolayısıyla hedeflenen sonuca hızlı ve etkin bir biçimde ulaşma arzusunda bulundukları gibi etmenlerin belirleyici olduğu anlaşılmaktadır.

Diğer yandan şiddeti bir yöntem olarak kullanmayı benimsemiş terör örgütlerinin insan kaynağı ihtiyaçlarını giderme adına psikolojik süreçleri etkin bir şekilde kullanmakta oldukları bilinmektedir. Buna göre örgüte kazandırılması planlanan kişilere öncelikle (sözde) karşılıksız arkadaşlık ve dostluk sunularak duygusal bir yaklaşımda bulunulmakta, ardından kişiye birtakım sorumluluklar yüklenerek grup aidiyetleri pekiştirilmektedir. Dolayısıyla, bu yöntemle kişinin kapalı kolektif bir topluluğun içinde örgüt eliyle oluşturulacak gerçeklik algısını edinmeye hazır hale getirilmesi, belirlenen hedefler doğrultusunda düşünsel seviyelerinin yükseltilmesi ve nihai olarak eyleme katkı sağlayacak bir duruma taşınması mümkün olabilecektir. ${ }^{43}$

Son dönemlerde İslam toplumlarında -bir biçimde- yer bulan terör örgütlerinin, kamuoyunda infial oluşturacak türde eylemlerde bulundukları görülmektedir. Zira bu tercihte, eylemin hedef toplumda uyandıracağı etki hacminin büyüklüğü ve yaygınlık derecesi temel kriteri oluşturmaktadır. Başka bir ifadeyle psikolojik bir hedef

\footnotetext{
41 Terörizmin psikolojik açıdan ayrıntılı olarak tahlili için bkz. Doğu Ergil, “Terörizmin Mantı̆̆ı ve Hedefi", Ankara Üniversitesi Siyasal Bilimler Fakültesi Dergisi, Ankara: Siyasal Bilgiler Fakültesi Yayınları, (1991), c. XLVI, sayı:1-2.

42 Rex A. Hudson, The Sociology and Psychology of Terrorism: Who Becomes a Terrorist and Why?, Washington: The Library of Congress, (1999), s. 23-29.

43 Ayrıntılı bilgi için bkz. Necati Alkan, Psikolojik Harekat, Terörizm ve Polis, Ankara: TEMÜH Dairesi Başkanlığı Yayınları, (2000).
} 
olarak, terörist eylemlerin hedef toplumu çözücü, sindirici ve izole edici kaotik etkisinin verimliliği öncelikli belirleyendir. ${ }^{44}$ Özellikle DAİş gibi adından sıklıkla söz ettiren terör örgütlerinin elinde etkili tiyatral bir gösteri olarak sunumlanan eylemler, hedef kitleye (tüm dünya) ulaştırılmak istenen mesajın en etkin bir biçimde gönderilmesi amacina hizmet etmektedir.

Songar' 1 if ifadesiyle ${ }^{45}$ terörizmin sürekli terör, cinayet ve sabotajlarla toplumu "korku hipnozu"na sokmak ve bireylerin muhakeme gücünü kırarak doğru ve yanlışın ayırt edilemez bir hal almasını sağlamak şeklinde ifadelendirilebilecek iki temel amacı bulunmaktadır. Bu haliyle adeta hipnotize olmuş, suskun ve itaatkar bir karaktere bürünmüş olan toplumun, içine girdiği kaos durumunda, öncesinde tamamen reddetmiş olduğu şeyleri dahi kabul edecek yeni bir hal alabilmesi mümkün olacaktır.

Diğer taraftan baskıcı ve otoriteryan idarelerce yönetilen ülkelerde gözlemlenen yolsuzluklar, ekonomideki dengesiz dağılım, işsizlik ve fakirlik oranlarındaki yükseklik gibi hususların özellikle genç kitleler üzerinde hayal kırıklığı, çaresizlik hissi ve şiddete eğilimli bir tepkiselliğin gelişimini salık verdiği tespit edilmelidir. Söz konusu tepkiselliğin ürettiği agresif davranış biçimlerinin de süreç içinde kimi kurumsal yapılara yahut bizzat devlet erkine yönelik organize şiddet eylemlerine dönüşebilme riski taşıdığı açıktır.

\section{(ii) Sosyo-Politik ve Sosyo-Ekonomik Zemin}

Radikalleşmeye zemin hazırlaması muhtemel sosyo-politik ve soyoekonomik faktörleri genel bir çerçeveyle, toplumda etnik, dini yahut mezhep ayrılıklarının varlı̆̆ı, genel eğitim düzeyinin düşüklüğü, ötekileşme, bireysel ve toplumsal özgürlüklerin kısıtlllığı, ideolojik kamplaşmaların varlığı, ülkedeki yönetim ve hükümetin yetersizliği, toplumdaki bazı grupların bürokraside ayrıcalıklı konumları ele geçirmesi, siyasi partiler arasındaki çekişmelerin toplumsal bölünmelere yol açması, yargı, yürütme ve yasama erkleri arasındaki uyumsuzluk ve kronikleşmiş hükümet krizleri, güvenlik güçlerinin kamuoyu itibarının zedelenmişliği, hukuki kurumların taraf haline

44 Tuncer Günay, Türkiye'de Terör ve Terörizm, Ankara: Berikan Yayınevi, (2001), s. 51.

45 Ayhan Songar, "Psikolojik Açıdan Toplumda Şiddet", İstanbul Üniversitesi Hukuk Fakültesi Mecmuası, İstanbul: İstanbul Üniversitesi Hukuk Fakültesi Yayınları, (1982-1983), c. 48, say1:1-4, s. 445-446. 
gelmesi, toplumun adalete olan inancinin sarsılması, toplumsal birlik anlayışının kaybedilmesi, toplumdaki gelir dağılımı dengesizliği, ekonomik dağılımdaki düzensizliğin toplumsal sınıflaşmayı tetiklemesi, artan işsizlik oranları, ekonomik dış bağımlılık, ekonomi kurumlarındaki yetersizlik ve yolsuzluklar, devletin ekonomik kontrolü kaybetmesi ve diş ekonomik angajmanlar türünden faktörler ${ }^{46}$ şeklinde sıralamak mümkün görünmektedir.

Ulusal yahut uluslararası düzeyde bir radikalleşme ve buna bağlı olarak gelişen terörizm tehdidinin oluşturulabilmesi için asgari olarak bir kitlenin benimseyerek destekleyebileceği bir ideoloji/amaç, bu ideoloji veya amacın gereklerinin yerine getirilmesini engelleyen gerçek ya da hayali olarak üretilmiş bir "düşman/öteki", amaca giden adımları oluşturan eylemleri gerçekleştirebilecek düzeyde ideolojik ve uygulamalı eğitim almış militanlardan oluşan bir örgüt, bu örgütü ve destekleyici kitleyi yönetsel olarak idare edebilecek bir lider, eylem sahasını lojistik olarak destekleyecek (araç-gereç, silah mühimmat vs.) finansman kaynağı, eylemin istenen sonucu oluşturabilmesi için gerekli uygun toplumsal-siyasal-ekonomik istikrarsızlık ortamı, örgütün çeşitli zorluklarla karşılaştı̆̆ında sığınabileceği ülke içi ya da dışında güvenli üs ve bölgeler, ulusal ve uluslararası düzeyde propaganda araçları ve daha birçok olanak gereklidir. ${ }^{47}$ Kuşkusuz bu gereksinimler hiçbir şekilde kendiliğinden ve doğal olarak bir araya gelemez. Dolayısıyla mutlak surette kimi güçler tarafından bir araya getirilmeleri ve koordine edilmeleri gerekmektedir. Başka bir deyişle terörizm, bir ülkenin, dinin yahut etnik yapının özelliklerinden ve içinde bulunduğu toplumsal yapının özgün koşullarından yararlanılarak bazı güç odaklarınca oluşturulmaktadır. Buna olanak sağlayan koşullar ise terörizmin oluşumunu mümkün kılacak bir istikrarsızlık ortamı, bu istikrarsızlığı sürdürebilmeyi sağlayacak toplumsal farklılık ve ayrım noktalarının bulunması -yoksa oluşturulması- ve bunların çeşitli düzeylerde istismarının gerçekleştirilmesi şeklinde özetlenebilir.

Terör eylemleri genel olarak iki motivasyondan hareket etmektedir. Bunlar, siyasal ve toplumsal adaletsizlik düşüncesinin varlığ ile şiddetin sistem değişikliğini sağlayacağına yönelik inançtır. Buna göre toplumda görülen sosyo-ekonomik dengesizlikler yahut

46 Türkiye Barolar Birliği, a.g.e., s. 142-143.

47 Türkiye Barolar Birliği, a.g.e., s. 306. 
adaletsizliği gidermenin yolu şiddete başvurmaktan geçmektedir. Zira toplumsal adaletin sağlanmasında önemli görevler üstlenen ülke içi hukuk müesseselerinin, mahkemelerin ve yasaların yozlaşması, bunların toplumda yer bulan kimi grupları kayırıcı bir formda işlemesi dolayısıyla eşitlik ve adalet anlayışı ortadan kalkmış olmaktadır. Bu durum hukuk mekanizmasının olmadığı bir yapıda kişi yahut grupların kendilerince oluşturdukları adalet anlayışlarını tesis etmeye yönelik çabalara destek verebilecek bir toplumsal taban sağlayabilmektedir.

Diğer yandan terör söz konusu edildiğinde göz ardı edilemeyecek önemli konulardan biri kuşkusuz terörün finansman desteğinin sağlanmasıdır. Zira gerçekleştirilecek her bir eylemin, mahiyeti ve büyüklügü oranında bir finansal desteğe ihtiyaç duyduğu açıktır. Dolayısıyla bu faaliyetler için örgütlerin vakıf, dernek yahut hayır kurumu gibi çeşitli isimler altında etkinlik yürüten ve kendi destekçilerinden fon akışını sağlayan yapılanmaları bulunmaktadır. Bununla birlikte kimi örgütlerin finans kaynakları arasında fidyeden uyuş̧turucuya işlevselleştirilmiş pek çok yasadışı destek kanalının bulunduğu bilinmektedir.

Özelde halkının büyük çoğunluğu Müslüman olan kimi ülke yönetimlerinin, toplumda kendilerine karşı siyasal muhalefet içinde bulunan gruplara yönelik baskıcı ve onları sindirmeye dönük bir politika izlemeleri, zaman zaman bu politikaların devlet terörüne dönüşmesi gibi uçlara varmakta, bu da muhalif yapının kendine özgü bir biçimde geliştirdiği savunma stratejilerini ortaya koymasına sebep olabilmektedir. Özellikle son yüzyılda İslam toplumlarında yaşanan sıkıntılar, küresel hegemonyal güçlerin güdümünde Ortadoğu'da kurulan devlet yönetimlerinin kendi halklarının düşünsel ve maddi kaynaklarını sömürüye açmaları, halkın doğrudan kendi taleplerini ifade edebilecek siyasi mekanizmaları oluşturmasından mahrum bırakılması yahut bunların tehlike olarak görülmeleri ve kimi durumlarda şiddetle tasfiye edilmeleri, kitlesel anlamda radikalleşme eğrisinin ivme kazanmasına katkı sağlayıcı türde etkide bulunmaktadır. Bu bağlamda örneğin Mısır'da etkin olan İhvan-1 Müslimin, Tunus'ta varlık gösteren Nahda hareketi (Hizbu'nNehda), Cezayir'deki Ulusal İslami Cephe hareketi ve Pakistan'da kurulmuş olan Cemaat-i İslami hareketleri mevcut yönetsel yapıya 
alternatif modeller olarak ortaya çıkmış, ancak idaresi altında bulundukları yönetimlerce siyasi birer tehlike oluşturdukları gerekçesiyle zaman zaman şiddetli baskıya maruz kalmışlardır. Bu çerçevede, söz konusu alternatif yapılanmalara yönelik uygulamaya konan kovuşturmalar sonucu, muhalifler, çeşitli siyasi suçlarla itham edilerek mahkumiyetlere ve işkencelere maruz bırakılmıştır. ${ }^{48}$ Tunus'taki Nahda hareketinin kurucuları arasında öne çıkan isimlerden biri olan Raşid el- Gannuşi'nin de aralarında bulunduğu İslami Eğilim Partisi'nin liderlerinin tutuklanarak hapsedilmesi, Misır'da son dönemde İhvan hareketine mensup olan Cumhurbaşkanı Muhammed Mursi ve ekibinin askeri darbe ile görevlerinden el çektirilerek siyasi suçlu olarak mahkum edilmeleri bu durumu örnekler niteliktedir. Ortaya konan bu türden şiddet uygulamaları kuşkusuz radikalleşme potansiyellerinin hızlı bir şekilde işlerlik kazanmasında etkili olmakta ve karşı şiddet oluşumuna zemin hazırlamaktadır. Nitekim Mısır'da İhvan-1 Müslimin hareketine karşı sert tutumuyla bilinen Enver Sedat'ın İslami Cihad örgütünün düzenlediği bir suikastla öldürülmesi ${ }^{49}$ türünden olaylar söz konusu refleksi kayıtlamaktadır.

Diğer taraftan seçkinci bir azınlık tarafından idare edilen Ortadoğu ülkelerinde yakın dönemde görülen ve Arap bahart ${ }^{50}$ olarak isimlendirilen yönetim karşıtı halk hareketlerinin başta Tunus olmak üzere Mısır, Suriye, Libya, Ürdün ve Yemen gibi birçok ülkeyi siyasi açıdan önemli derecede etkileyen bir dönüşüme sürüklediği bilinmektedir. Söz konusu siyasi hareketliliğin yaşandığı süreç, özellikle şiddet yanlısı radikal oluşumların da hareket alanı bulmalarına uygun bir zemin oluşturmuştur. Zira bu türden örgütlenmelerin temsil iddiasında bulunduğu toplumsal tabandan hareketle amaçladığı hedef, kendi özerkliğine sahip bir devlet yapılanmasının ikame edilmesidir. Dolayısıyla çatışma ve siyasal kriz ortamları

${ }^{48}$ Talip Küçükcan, "Modernleşme ve Sekülerleşme Kuramları Bağlamında Din, Toplumsal Değişme ve İslam Dünyası", İslam Araştırmaları Dergisi, (2005), sayı:13, s. 121-123.

${ }^{49}$ Adnan Demircan, Çağdaş İslami Hareketler ve Şiddet Sorunu, İstanbul: Beyan Yayınları, (2015), s. 69.

${ }^{50}$ Genel isimlendirmenin dışında "Arap Uyanışı", "Yasemin Devrimi”, ve "Nilüfer Devrimi" gibi farklı tanımlamalarla ilgili ayrıntılı bilgi için bkz. Tarık Oğuzlu, "Arap Baharı ve Yansımaları", Ortadoğu Analiz, (2011), c. 3, sayı: 36, s. 8-16; Hüsamettin İnaç, "Arap Baharı Sürecinde Arap Kimliğinin Dönüşümü", Ortadoğu Yıllığı, (2011), sayı: 7, s. 487-501. 
böylesi oluşumların alan genişletmesi adına merkezi hükümetin askeri harcamalarını dayanılmaz düzeylere taşıyarak ilgili yönetimin zora sokulmasını sağlamaya dönük manipülasyonlar için uygun imkanlar üretmektedir.

Öte yandan Afrika sömürgeleri, İsrail'in yıllar süren Filistin (Batı Şeria) işgali, Bosna ve Çeçenistan savaşları, 11 Eylül saldırılarının ardından ABD tarafından Afganistan ve Irak'ın işgal edilmesi, Ebu Garib hapishanelerindeki işkence görüntülerinin küresel medya aracılığıyla dolaşıma girmesi türünden gelişmeler, özellikle bölgede terör ve karşı şiddet oluşumuna yönelik hazırlayıcı bir zeminin varlık kazanmasında diğer yardımcı unsurlar olarak zikredilebilir. Zira II. Dünya savaşı sonrası Ortadoğu'da hayata geçirilen baskıcı yönetimlere dayalı mekanizmalar, bölge halkının kümülatif olarak artan toplumsal öfkesini yadsıma yoluna gitmiş, ancak bu durum Arap Baharı süreciyle yeni birtakım dinamiklerin devreye girmesini olanaklı kılmıştır. Özellikle işgalcilere karşı bir direniş geliştirme anlam zeminini kullanan DAİş gibi yapılanmaların tam da böylesi bir noktada mezhep gerilimlerinden yararlanarak (Sünnilik merkezli) Suriye ve Irak eksenli alan genişletme çabalarının, en azından bu genişlemeye dönük uygun imkanlar oluşturduklarının hatırlanması yerinde olacaktır.

Radikalleşmeye iten sebepler, Ortadoğu ve Batı Avrupa/ABD örneklerinde kuşkusuz birbirinden farklı sosyolojik temellerden beslenmektedir. Bu çerçevede özellikle batıda yaşayan Müslümanların radikalleşme süreçlerinde iki kültür arasında sıkışmışlık, kamusal alanda etnik ve dini aidiyetlerinden ötürü sosyo-kültürel ve ekonomik ayrımcılığa maruz kalmaları gibi problemlerle yüzleşmeleri türünden etkenlerin öne çıktığ görülmektedir. ${ }^{51 B o ̈ y l e s i ~ d e n e-~}$ yimler, içinde bulunulan topluma dönük güvensizlik ve öfkeyle örülü bir marjinalleşme sürecini doğurmaktadır. Dolayısıyla bu da kendilerini toplumun ötekisi olarak hissetmeye başlayan kimseleri marjinalliğe iten tüm sebeplerden intikam alma motivasyonuna dahil etmektedir. Zaten radikalleşmenin şiddet ve terörle ilişkili bir formda düşünsel olarak onaylanmaya başladığı açıklık tam da bu

${ }^{51}$ Avrupa' da yaşayan Müslümanların kimlik temelli problem alanlarının ayrıntılı tahlili için bkz. Fatih Yaman, Sivil Toplum Bağlaminda Avrupa'da İslam ve Müslüman Kimliği: Almanya Örneği, (Yayınlanmamış Doktora Tezi), İstanbul Üniversitesi Sosyal Bilimler Enstitüsü, İstanbul, (2015). 
noktada işlerlik kazanmaktadır. Zira dini argümantasyonla şiddeti uyumlu bir ilişki halinde sunumlayan terör örgütleri, gerek mühtediler gerekse batıya öfke duyan kimselere kendilerini bilfiil gerçekleştirecek bir alan sunmaktadırlar. Bu alan bir taraftan o ana kadar geride kalan zamanla ilgili hızlı bir telafi mekanizmasını devreye sokmakta, diğer taraftan adaletsizliğe son verecek "ideal bir İslam devleti" kurulması vaadiyle, gerçekleşmesi muhtemel bireysel ve toplumsal refah durumunu imlemektedir. Kuşkusuz bu motivasyonun sağlanmasında kullanılan araçlar ve dil önemli bir etki potansiyeline sahiptir. $\mathrm{Bu}$ açıdan bakıldığında radikal örgütlerin profesyonelce hazırlanmış içeriklerle internet ve sosyal medyayı son derece etkin birer araç olarak kullandıkları dikkat çekmektedir. Özellikle internet üzerinden yayınlanan video görüntülerin hazırlanmasında ihtiyaç duyulan profesyonel yapım teknikleri, kullanılan yüksek çözünürlük kalitesi ve konuşmaların aksansız bir İngilizce ile aktarılması verilmek istenen mesajın küresel ölçekte en kullanışlı yollarla iletilmesini sağlamaktadır. Söz konusu yayınlardaki aktif propaganda dizinlerinde ise İslam literatüründe yer bulan cihat, kıtal, şehadet, hilafet ve hicret gibi kavramların, muhtemel sempatizanların teşvik edilmesi ve örgüte aktif katılımlarının sağlanabilmesi adına öne çıkarıldığı görülmektedir.

\section{(iii) Metne Radikal Yaklaşım}

Genellikle herhangi bir dini gelenek ile şiddet yahut radikal eylem örneklerinin ilişkiselliğinden söz edilirken, yöntem olarak ilgili inancın kutsal saydığı metinlere ve bunların uygulanması ya da uygulanmamasından kaynaklı tarihsel gerçeklerle metnin uyumsuzluğuna dikkat çekilerek varlık bulan çelişkilere odaklanılmaktadır. Oysa yalın olarak metin, kendini hemen her türden anlamaya uygun bir olanak sunmaktadır. ${ }^{22}$ Başka bir deyişle metin hermenötiğinin zorunlu olarak devreye sokulması gereken bir aşama olarak bu

\footnotetext{
52 Dinsel metnin şiddet üreten bir tarzda anlaşılmasına dönük uygulamaları ele alan çalışmaları örneklemesi bakımından bkz. Grace Hallsell, Tanrıyı Kıyamete Zorlamak, (Çev.), M. Acar, H. Özmen, Ankara: Kim Yayınları, (2002); Israel Shahak, Yahudi Tarihi Yahudi Dini, (Çev.), Ahmet Emin Dağ, İstanbul: Anka Yayınları, (2002).
} 
noktada metnin kendisinin şiddet yanlısı olmasa da farklı okumalara imkan tanıması ve bu çerçevede okumalardan bazılarının barışçıl bazılarının ise şiddet yanlısı olması kaçınılmaz olmaktadır. ${ }^{53}$

$\mathrm{Bu}$ bakış açısından hareketle örneğin kimi dini geleneklerde öne çıkan kanlı kurban ibadetlerinden, ${ }^{54}$ Ortaçağ'da yer alan Haçlı seferleri yahut İslam tarihindeki cihat hareketlerinden yola çıkılarak söz konusu inançların sosyal ve teolojik düzeyde şiddet ürettiği sonucuna varılması dahi mümkün olabilmektedir. ${ }^{55}$ Ancak yukarıda ifade edildiği gibi, insanın mutluluğunu tesis etmeyi temel hedef olarak konumlayan dinlerin şiddete davet etmemekle birlikte birtakım siyasi yahut ideolojik amaçlar gözetilerek geliştirilen istismarla din adına şiddete yönelimlerin gerçekleştiği bilinmektedir. Başka bir deyişle şiddet, insanoğlunun düşünsel manipülatif çabasıyla dini ve kültürel sınırları anlamsızlaştırarak hemen her öğreti içinde kendine yeterli alan oluşturabilir. Buradan hareketle, içinde yaşanılan modern dönemde, başta İslam olmak üzere çeşitli dini anlayışların öne çıarılarak gerçekleştirildiği gözlemlenen şiddet ve terör olaylarının bu farkındalıkla ele alınması gerekmektedir.

Kuşkusuz şiddet eylemlerinin meşruiyetinin sağlanması bağlamında dayanak alınan kutsal metnin okuma ve anlama biçimiyle ilgili birtakım analizlerin yapılması önem taşımaktadır. Zira metnin anlaşılmasıyla ilgili yöntem probleminin çözümlenmemesi, şiddet yanlısı radikal eyleme biçimlerinin önüne geçilmesine dönük çabaların eksik kalmasına sebep olabilecektir.

Özellikle son dönemlerde Ortadoğu'da şiddeti etkin bir enstrüman olarak kullandığı gözlemlenen DAİş ve El-Kaide gibi terör örgütlerinin kendilerince bir meşruiyet oluşturma çabalarının arkasında, sözü edilen yöntemle İslam'ın temel kaynaklarını referans aldıkları bilinmektedir. Bu yaklaşımda belirleyici olan, İslam tarihinde "Selefiyye" olarak adlandırılan ekolden hareketle kendini konumlayan ve bugün modern bir ideoloji halinde sunumlanan

\footnotetext{
53 Ibrahim Kalın, "Islam and Peace: A Survey of the Sources of Peace in the Islamic Tradition", Islamic Studies, (2005), 44:3, s. 329-352.

${ }_{54}$ Bkz. Rene Girard, Violence and the Sacred, (Çev.), Patrick Gregory, Baltimore:

The Johns Hopkins University Press, (1979).

55 İbrahim Kalın, a.g.e., s. 327.
} 
"Selefilik" hareketinin ${ }^{56}$ İslami yorum biçimidir. Buna göre öze dönüş düşüncesine merkezi bir rol atfeden Selefilik, İslam'ın ilk yıllarındaki saflık ve katışıksızlığa dönülmesini hedeflemekte; bu anlamda söz konusu saflığa zarar verici unsurlar olarak değerlendirilen bidatlerle mücadeleyi esas almaktadır. ${ }^{57}$ Selefiliğin din anlayışında konumuz çerçevesinde öne çıkarılması gereken bazı hususlar şöyle özetlenebilir:

- Müteşabih ayetleri ve haberi sıfatları tevil etmek caiz değildir.

- Tevhidin, rububiyet, uluhiyet ve amelle ilişkisi bulunmaktadır. Bu hususta ameli eksikliği olan kişi kafir olur.

- Şirke ve küfre müsamaha gösterilemez.

- Müminleri dost edinip imansizlardan uzaklaşmak ve onlara düşman olmak en önemli itikadi esaslardandır.

- Türbelere tazimde bulunan, imamların masumluğunu kabul eden ve ilk üç halife başta olmak üzere bazı sahabeleri kötüleyen Şiiler, müşrik ve kafirdirler.

- Yanlış yapan ve günah işleyen kişilerle mücadele etmek Müslümanın asli görevlerindendir. ${ }^{58}$

Görüldüğü üzere bu esaslar şiddet içerikli bir eylem alanını inşa etme noktasında kolaylıkla işlevselleştirilebilir bir nitelik taşımaktadır. Zaten DAEŞ ve El-Kaide türünden yapılanmaların eylem örneklerinde sıklıkla referansta bulundukları ayet yahut hadis metinlerinin literal bir okumayla ve bağlamından koparılarak şiddet üretimine araç kılındıkları bilinmektedir. Esasen İslam'ın yalnızca hoşgörü ve tolerans sınır genişliğinin tarihsel örneklerine bakılmasının dahi radikal selefiliğin ${ }^{59}$ ortaya koyduğu küfür tanımlaması ve

\footnotetext{
56 Adnan Demircan, a.g.e., s. 65.

57 Mehmet Zeki İşcan, "Selefiliğin Temel Esasları ve Sosyo-Politik Arka Plan", Tarihte ve Günümüzde Selefilik, İstanbul: Ensar Yayınları, (2014), s.103.

58 Mehmet Ali Büyükkara, “Günümüzde Selefilik ve İslami Hareketlere Olan Etkisi”, Tarihte ve Günümüzde Selefilik, İstanbul: Ensar Yayınları, (2014), s. 486-487. 59 Dini ideolojik bir zor kullanma aracına dönüştürerek, siyasi katılım yollarını reddeden ve zora dayalı eylem yoluyla dönüşümü dayatan İslami hareketlerin bu çatı kavram içinde değerlendirilmesini önermekteyken, Büyükkara, şiddeti
} 
bununla mücadele yolunu yanlışladığını görmek zor değildir. Dolayısıyla, radikal selefi düşüncenin temel İslami kavramları yapı-bozuma uğratarak içlerini boşaltması, İslami literatürde genellikle zayıf olarak görülen apokaliptik rivayetler üzerinden bir kıyamet senaryosu kurgulayarak kendisine meşruiyet oluşturması, kendilerine benzemeyenleri sapkınlık ve dinden çıkmakla itham etmeleri türünden yaklaşımları, bu düşüncenin epistemolojik ve metodolojik sapmaları olarak değerlendirilmelidir. ${ }^{60}$

Bununla birlikte, yukarıda yer verilen din anlayışı çerçevesinden hareketle, kendileri dışındaki Müslümanların kapsamlı bir biçimde ötekileştirilmesi yoluna giden radikal selefi anlayışın mezhep çatışmalarına zemin hazırlayarak toplumsal bölünmeyi artırdığını tespit etmek yerinde olacaktır. Bu bağlamda, kullanıma sokulan terörün ihtiyaç duyduğu insan gücü ihtiyacının karşılanmasında din etkili bir manipülatif araç olarak işlevselleşebilmekte; özellikle erken yaşlardaki çocuk ve gençlerin zihinsel gelişiminde nefret yüklü bir öteki imajı kurulumuna hizmet etmeye uygun şekilde kullanılabilmektedir. Bu da son noktada tüm şiddet eylemlerini bir biçimde dini bir temelle haklılaştırma yolunu -en azından bu kimselere- açık etmektedir.

Diğer taraftan özellikle İslami bilgiyi belirli bir usul ve gelenek içinde almamış, hayatının önemli bir bölümünü seküler bir çizgide sürdürmüş, ancak sonradan dini bir hayat sürmeye karar kılmış yahut farklı bir inanıştan ihtida ederek İslam'ı seçmiş kimselerin görece kesin ve net çizgilerle sınırlarını açık eden böylesi yorumlara iltifat edebildikleri de kayıtlanması gereken bir diğer önemli hususu teşkil etmektedir.

Zira Ortadoğu'da konumlanan terör örgütlerinin insan kaynağının azımsanamayacak bir bölümünün Avrupa'dan bu gruplara

\footnotetext{
yöntem olarak benimseyen söz konusu örgütlerin "Cihadi Selefiyye" olarak değerlendirilmesini önermektedir. Bkz. Hilmi Demir, Radikal Selefi Hareketler ve Terör Örgütleri: Kavram ve Teorik Çerçeve, (Değerlendirme Notu), Türkiye Ekonomi Politikaları Araştırma Vakfı, (2016), s. 3; Mehmet Ali Büyükkara, “Günümüzde Selefilik ve İslami Hareketlere Olan Etkisi", Tarihte ve Günümüzde Selefilik, İstanbul: Ensar Yayınları, (2014), s. 489.

${ }^{60}$ Din İşleri Yüksek Kurulu, Daiş'in Temel Felsefesi ve Dini Referanslar Raporu, Ankara, (2015), s. 8.
} 
yapılan genç katılımcılarla şekillendiği bilinmektedir. ${ }^{61}$ Özellikle doğup büyümüş oldukları toplumsal yapı içinde orta sınıfa ait oldukları gözlemlenen bu gençlerin kendi toplumlarına yönelik aidiyetlerinin bir biçimde zarar görmüş olduğu; kendilerini dışlanmış "öteki"ler şeklinde hissetmelerine bağlı olarak gelişen bir intikam duygusuyla hareket ettikleri ve nihayetinde terör örgütlerine dahil oldukları sonucu çıkarsanabilir.

Öte yandan Batı ülkelerinin herhangi birinde cereyan eden şiddet yüklü bir eylemin, kamuoyu yapıcıları tarafından -medyanın da kullanımıyla- tüm Müslümanları teşmil eden bir yaklaşımla eleştiriye açılması, bunun çıtılarının söz konusu ülkelerde yaşayan Müslümanlarca çeşitli derecelerde kötü muameleye maruz kalmaları türünden sonuçlar doğurmaktadır. Dolayısıyla bu noktada radikal örgütlere katılımın, doğrudan dini bir saikle ilişkilendirilmesinden çok, toplumsal dışlanma ve sosyal değer kaybının iyileştirilerek yeniden ikame edilmesi adına tedavüle konulan bir telafi ve intikam mekanizmasıyla açıklanması uygun görünmektedir.

\section{Sonuç}

Radikalleşme ve terör, günümüzün aşılması belki de en zor sorunlarından biri olarak önümüzde durmaktadır. Özellikle teknoloji ve kitle iletişimin ulaştığı sınır ötesi boyutlar ve küreselleşmeyle gelişen mekânsal daralmanın bir aradalığı dikkate alındığında, dünyanın hemen her yerinde benzeri güvenlik problemleriyle karşı karşıya gelinebilmektedir. Ancak yaygınlaşan radikalleşme ve şiddet, yalnızca bir güvenlik sorunu olarak ele alınmamalı, bunun yanı sıra konunun psikolojik, sosyal, ekonomik ve siyasal boyutları da değerlendirmeye ortak edilmelidir.

Radikalleşmeyle mücadelede demokratik ilkelerin ihlal edilmesi daha geniş siyasal tahribata neden olmakta ve uzun dönemli olumsuz etkilerin oluşumuna ortam hazırlamaktadır. Radikal şiddet yanlısı örgütlerin gerek ekonomik gerekse lojistik destek bulmakta zorlanmadıkları gerçeği, bugün devletler arasında tesis edilmesi gerekli olan işbirliğinin önemini kayıtlamaktadır. Bu an-

${ }^{61}$ Constanze Letsch, "Foreign jihadis change face of Syrian civilwar," the Guardian, 25 December 2014, [Erişim tarihi: 19 Eylül 2016], http://www.theguardian.com/world/2014/dec/25/foreign-jihadis-syrian-civil-war-assad. 
lamda terörle mücadelede ortak stratejiler oluşturmak, ancak ülkelerin birbirlerinin deneyimlerinden yararlanmasıyla mümkün olabilecektir.62 Dolayısıyla geliştirilecek olan öncelikli strateji, radikalleşmeye sebep olan unsurların ortadan kaldırılmasına yönelik olmalıdır.

Bu noktadan hareketle, çatışma ve şiddet üreten dini yorumun İslam'ı temsil etmekten uzak bir anlayış geliştirmiş olduğu temasının entelektüel bilgi üretiminde merkezi bir şekilde ele alınması, öte yandan sosyo-ekonomik adaletsizliklerin ortadan kaldırılabilmesi için güçlü bir siyasi iradenin ortaya konması, sivil toplum kanallarının radikalleşme ve terör karşısında ortak bir mobilizasyonla hareket etmesinin sağlanması, tarih boyunca deneyimlenen hoşgörü ve farklılıklarla bir arada yaşama tecrübesinin dayanak alınarak, İslam inancının toplumsal dışlayıcılığı reddettiğinin somut ve pratik düzleme taşınma imkanının geliştirilmesi, radikalleşmenin önlenmesinde başlıca öne çıkan tedbirler olarak görülmektedir.

\section{Kaynakça}

Ayhan Songar, "Psikolojik Açıdan Toplumda Şiddet", İstanbul Üniversitesi Hukuk Fakültesi Mecmuası, İstanbul: İstanbul Üniversitesi Hukuk Fakültesi Yayınları, (1982-1983), c. 48, sayı:1-4.

Adnan Demircan, Çă̆daş İslami Hareketler ve Şiddet Sorunu, İstanbul: Beyan Yayınları, (2015).

Ahmet Emin Dağ, Uluslararası İlişkiler ve Diplomasi Sözlüğ̈̈, İstanbul: Anka Yayınevi, (2004).

Antonio Cassese, Terrorism, Politics and Law: The Achille Lauro Affair, Cambridge: Polity Press, (1989).

Beverley Milton-Edwards, Islamic Fundamentalism since 1945, London:

Routledge, (2005).

Cas Mudde, "The War of Words Defining the Extreme Right Party Family", West European Politics, (1996), sayı: 24

Constanze Letsch, "Foreign jihadis change face of Syrian civilwar," the Guardian, 25 December 2014, [Erişim tarihi: 19 Eylül 2016], http://www.theguardian.com/world/2014/dec/25/foreign-jihadissyrian-civil-war-assad.

Din İşleri Yüksek Kurulu, Daiş'in Temel Felsefesi ve Dini Referanslar Raporu, Ankara, (2015).

62 Günay, a.g.e., s. 57-58. 
Doğu Ergil, Türkiye'de Terör ve Şiddet, Ankara: Turhan Kitabevi, (1980).

“Terörizmin Mantığı ve Hedefi”, Ankara Üniversitesi Siyasal Bilimler

Fakültesi Dergisi, Ankara: Siyasal Bilgiler Fakültesi Yayınları, (1991),

c. XLVI, sayı:1-2

Emin Gürses , Etnik Terör, İstanbul: Profil Yayıncılık, (2007).

Fatih Yamaç, Siber Terörizm", Polis Dergisi, (2001).

Fatih Yaman, Sivil Toplum Bağlamında Avrupa'da İslam ve Müslüman Kimliği: Almanya Örneği, (Yayınlanmamış Doktora Tezi), İstanbul Üniversitesi Sosyal Bilimler Enstitüsü, İstanbul, (2015).

Giovanni Sartori , "Concept Misinformation to Comperative Politics", American Political Science Review, 64 (1970).

Grace Hallsell, Tanrıyı Kıyamete Zorlamak, (Çev.), M. Acar, H. Özmen, Ankara: Kim Yayınları, (2002).

Haluk Yavuzer ,Çocuk Psikolojisi, İstanbul: Remzi Kitabevi, (2005).

Hasan Saim Vural, Avrupa'da Radikal Sağın Yükselişi, İstanbul: İletişim Yayınları, (2005).

Hayati Hazır, Siyasal Şiddet ve Terörizm, Ankara: Nobel Yayıncılık, (2001).

Hilmi Demir, Radikal Selefi Hareketler ve Terör Örgütleri: Kavram ve Teorik Çerçeve, (Değerlendirme Notu), Türkiye Ekonomi Politikaları Araştırma Vakfı, (2016).

İbrahim Kalın, "Islam and Peace: A Survey of the Sources of Peace in the Islamic Tradition", Islamic Studies, (2005), 44:3.

İhsan Bal, “Terör Nedir? Neden Terörist Olunur?”, Terörizm, (Der.), İhsan Bal, Ankara: Usak Yayınları, (2006).

Israel Shahak, Yahudi Tarihi Yahudi Dini, (Çev.), Ahmet Emin Dă̆, İstanbul: Anka Yayınları, (2002).

Javaid Rehman, Islamic State Practices, International Law and the Threat from Terrorism, Oxford: Hart Publishing, (2005).

Javaid Rehman and Susan C. Breau, Religion, Human Rights and International Law, London: Martinus Nijheff Publishers, (2007).

John L. Esposito, The Islamic Threat: Myth or Reality?, Oxford: Oxford University Press, (1992).

John Richard Thackrah, Dictionary of Terrorism, London: Routledge, (2004).

Kamu Düzeni ve Güvenliği Müsteşarlığı, Insan Hakları ve Terörle Mücadele, Ankara: Kamu Düzeni ve Güvenliği Müsteşarlığı Yayınları, (2011).

Klaus von Beyme, Right-Wing Extremism in Western Europe, London: Frank Cass, (1988).

Lawrence Davidson, Islamic Fundamentalism, California: Praeger, (2013). 
M. Şükrü Alparslan, Krimonoloji ve Hukuk Açısından Tedhişçilik, İstanbul: Teknik Yayınlar, (1983).

Mehmet Ali Büyükkara, “Günümüzde Selefilik ve İslami Hareketlere Olan Etkisi", Tarihte ve Günümüzde Selefilik, İstanbul: Ensar Yayınları, (2014).

Mehmet Zeki İşcan, "Selefiliğin Temel Esasları ve Sosyo-Politik Arka Plan", Tarihte ve Günümüzde Selefilik, İstanbul: Ensar Yayınları, (2014).

Michel Wieviorka, "Terrorism in the Context of Academic Research", (içinde) Martin A. Miller, P. Pomper vd., Terrorism in Context, (ed.) M. Crenshaw, Pennsylvania: The Pennsylvania State University Press, (1995).

Necati Alkan, Psikolojik Harekat, Terörizm ve Polis, Ankara: TEMÜH Dairesi Başkanlığı Yayınları, (2000).

Oliver Roy, The Failure of Political Islam, (Çev.), Carol Volk, London: I.B.Tauris, (1994).

Rene Girard, Violence and the Sacred, (Çev.), Patrick Gregory, Baltimore: The Johns Hopkins University Press, (1979).

Rex A. Hudson, The Sociology and Psychology of Terrorism: Who Becomes a Terrorist and Why?, Washington: The Library of Congress, (1999).

Rosalyn Higgins and Maurice Flory, Terrorism and International Law, London: Routledge, (1997).

Samuel P. Huntington, The Clash of Civilizations and the Remaking of World Order, London: Simon \& Schuster, (1996).

Şinasi Gündüz, Dinsel Şiddet, Samsun: Etüt Yayınları, (2002).

Talip Küçükcan, “Modernleşme ve Sekülerleşme Kuramları Bağlamında Din, Toplumsal Değişme ve İslam Dünyası", İslam Araştırmaları Dergisi, (2005), sayı:13.

“Demokrasi, Din ve Küresel Şiddet Eylemleri", İslam ve Şiddet, (Ed.), Mümtaz'er Türköne, İstanbul: Ufuk Kitap, (2007).

Tarık Oğuzlu, “Arap Baharı ve Yansımaları”, Ortadoğu Analiz, (2011), c. 3, sayı: 36. Hüsamettin İnaç, “Arap Baharı Sürecinde Arap Kimliğinin Dönüşümü”, Ortadoğu Yillığı, (2011), sayı: 7.

Ted Gurr, Why Men Rebel, New York: Routledge, (2011).

Tuncer Günay, Türkiye'de Terör ve Terörizm, Ankara: Berikan Yayınevi, (2001).

Türk Dil Kurumu, Türkçe Sözlük, Ankara: Türk Dil Kurumu Yayınları, (2005).

Türkiye Barolar Birliği, Türkiye ve Terörizm, Ankara: Şen Matbaa, (2006). 
İslam Toplumlarında Şiddet Yanlısı Radikalleșme Nedenleri

Walter Laqueur, Terrorism, Boston: Little, Brown, (1977), s. 125; Maxwell Taylor, The Terrorist. London: Brassey's, (1988).

William and Tom Bottomore, The Blackwell Dictionary of Twentieth-Century Social Thought, Oxford: Blackwell, (1993). 